ОСИПЕНКО Светлана Викторовна - кандидат исторических наук, доцент Военного университета Министерства обороны РФ (123001, Россия, г. Москва, ул. Садовая, 14; sv.osipenko2016@таil.ru)

\title{
ПРАВОВАЯ ШКОЛА М.М. СПЕРАНСКОГО: СТАНОВЛЕНИЕ ОТЕЧЕСТВЕННОЙ МОДЕЛИ СПЕЦИАЛИЗИРОВАННОЙ ЮРИДИЧЕСКОЙ ПОДГОТОВКИ
}

Аннотация. Научная концепция современной правовой политики государства ставит важную задачу перед научным сообществом - создание эффективной модели профессионального образования с опорой на исторический опыт. В статье представлен процесс становления и развития юридического образования в России первой половины XIX в., Автор отмечает вклад М.М. Сперанского в формирование процесса специализированной подготовки специалистов, преподавательского корпуса юридических учебных заведений в контексте исторических условий, влияния власти и общества на процесс реализации прогрессивного законодательного замысла, важной частью которого была реорганизация системы обучения.

Ключевые слова: юридическое образование, российское право, законоведение, студенты-правоведы, юридическая школа, юстиция

$\Phi$ ормирование российской правовой системы с учетом в первую очередь исторических и национальных особенностей и в сопоставлении со спецификой аналогичных мировых систем ставит перед исторической и юридической науками задачу по выработке научной концепции развития отечественной модели юридического образования. Проблема формирования исторического сознания в решении этого вопроса является ключевой. Без исторических знаний невозможно сформировать представление о культурных нормах, невозможно патриотическое воспитание, невозможен и сам процесс обучения, ибо в основе обучения любой науке лежит ее история. В исследовании внимание уделено вопросу становления отечественной модели юридического образования - правовой школы М.М. Сперанского.

Реформирование системы государственного управления в первой четверти XIX в. и последующие преобразования в системе законодательства приводят власть к осознанию необходимости перехода к подготовке для государственной службы чиновников, имеющих юридическое образование. Ранее правительственные меры были сведены к обеспечению минимальной юридической подготовки чиновников через среднее образование и введение «экзамена на чин», что, по сути, и явилось основой системы получения первоначальной правовой подготовки для лиц, претендующих на поступление на государственную службу.

Обеспечение кадрами развивающейся системы юридических учебных заведений (и учебных заведений в целом) в 1800-1850-х гг. являлось одним из приоритетных направлений в правительственной политике. Требовалось не только повышение уровня начальной профессиональной подготовки, но и создание системы специализированной юридической подготовки специалистов для качественного обучения законотворческой деятельности государственных служащих, которыми являлись ученые, учителя, врачи, инженеры, чиновники различного уровня.

Отсутствие единой программы в университетах, эклектический набор предоставляемых студентам-правоведам сведений из римского права, европейских теорий отдельных отраслей права и вольное комментирование из уст препо- 
давателей и читаемых самими же студентами российских узаконений соответствовали хаотическому состоянию как в сфере законодательства, так и в сфере практической юридической деятельности 1 [Кодан 2005].

В 1827 г. министр народного просвещения А.С. Шишков представил императору Николаю I общие положения по подготовке «истинно русских» профессоpoв $^{2}$, разработкой части специальной подготовки занимался М.М. Сперанский. Реформатор особое внимание уделял проработке тех вопросов, которые ему не удалось реализовать в 1809 г.

Создание М.М. Сперанским при II отделении Собственной е.и.в. канцелярии (далее - СЕИВ) «школы профессоров российского права» явилось прорывом в кадровом обеспечении российского юридического образования. 22 января 1828 г. он представил Николаю I записку о необходимости реорганизации системы подготовки европейски образованных профессоров-юристов, призванных восполнить недостаток кадров в университетах России, по мнению реформатора, для организации процесса обучения и специализированной юридической подготовки в России достаточного числа специалистов с «обширными познаниями». Подготовку профессоров Сперанский предложил начать непосредственно в стенах II отделения, совмещая с посещением лекций в Петербургском университете [Майков 1899а]. М.М. Сперанский представил императору подготовленный II отделением еще один доклад «О кандидатах законоведения» об организации подготовки преподавателей для учебных заведений на базе II отделения и предложил из Московской и Санкт-Петербургской духовных академий отобрать лучших студентов ${ }^{3}$. В марте 1828 г. были открыты курсы для «студентов кандидатов правоведения» по учебному плану, разработанному на 3 года.

Обучение в Берлинском университете первой группы студентов-правоведов началось осенью 1829 г. под руководством Ф.К. Савиньи, разработкой программы обучения занимался Сперанский. По воспоминаниям студента первой группы К.А. Неволина, они прослушали также курсы по: 1) энциклопедии прав вообще; 2) философии права; 3) истории и теории государственного права; 4) праву римскому; 5) германскому; 6) прусскому частному; 7) германскому и прусскому в совокупности; 8) европейскому народному4.

Осенью 1829 г. состоялся набор второй группы. Через 2 года, осенью 1831 г., они также отправились в Германию для дальнейшего обучения. В октябре 1832 г. в Россию возвратилась первая группа студентов-правоведов. Профессора Берлинского университета отказались принимать выпускные экзамены, поэтому экзамены решено было проводить в Петербурге, но затем их отложили на неопределенный срок, временно причислив студентов в апреле 1833 г. ко II отделению [Майков 1899б].

K 1834 г. М.М. Сперанский совместно с чиновниками II отделения и Министерства народного просвещения закончили разработку программы экзаменационного испытания для студентов-правоведов. В начале 1835 г. основные

1 В 1801-1804 гг. Л.И. Цветаев, профессор Московского университета по кафедре теории законов с 1805 г., изучал этико-политические науки в Геттингенском университете, а затем слушал университетские лекции в Париже. В 1808-1813 гг. там же обучался и будущий профессор права Главного педагогического института и Царскосельского лицея А.П. Куницын.

2 Предполагалось обучение в Дерпте - 2 года, затем в Париже и Берлине. См. ЦГИА. Ф. 418. Оп. 2 Д. 106. Л. 1-4(об).

3 Из Санкт-Петербургской - С.О. Богородский, С.Н. Орнатский, А. Пешехонов; из Московской А.А. Благовещенский, В.П. Знаменский, К.А. Неволин.

4 Речь Бутырского - декана философско-юридического факультета Санкт-Петербургского университета - по случаю публичной зашиты сочиненного рассуждения на степень доктора студентом законоведения К.А. Неволиным. - Журнал Министерства народного просвещения. 1835. № 2. С. 92. 
положения программы экзаменационного испытания были утверждены императором $^{1}$.

Программа испытаний выглядела следующим образом:

«Предметы испытания.

А) Общее систематическое обозрение законоведения...

В) Законы, определяющие права и обязанности.

C) Законы, охраняющие права как государственные, так и гражданские.

D) Историческое изложение Римского законодательства.

Е) Историческое изложение общего Немецкого законодательства» [Майков 18996].

Юридическая школа Сперанского дала импульс к формированию преподавательского корпуса юридических учебных заведений ${ }^{2}$. Ее выпускники внесли весомый вклад в развитие российской юридической школы. Все они с честью выдержали испытания и защитили диссертации: С.О. Богородский - «О философии уголовных законов у древних и новых народов», К.А. Неволин - «О философии законодательства у древних», А.А. Благовещенский - «История и метод науки законоведения в XVIII в.». Для студентов второго набора было решено отказаться от защиты диссертаций по определенной и специально разработанной теме и ограничиться «экзаменом прямо на доктора прав» и защитой тезисов исследования по юридической проблеме 3 . Выпускники школы М.М. Сперанского были первыми специалистами-законоведами, получившими классическое университетское образование в Европе, с практической подготовкой и участием в систематизации законодательства во II отделении. В середине XIX в. на юридических факультетах российских университетов служили уже 44 преподавателя.

Становление и развитие юридического образования в России первой половины XIX в. в целом соответствовало общественно-политическим процессам, характеру юридической политики и осуществлялось под влиянием западноевропейской юриспруденции, основополагающими идеями которой был поиск идеала политического и правового устройства государства. Созданная в результате реформ образовательная система специализированной юридической подготовки чиновников для государственного управления, гражданской и военной юстиции, хозяйственного управления, подготовки юристов для различных сфер государственной деятельности способствовала эффективной реализации

\footnotetext{
1 «Порядок испытания. 1. Испытание проводится через профессоров юридического факультета под председательством декана, вместе с депутатами от других факультетов и в присутствии управляющего II Отделением С.Е.И.В. Канцелярии и двух старших оного чиновников. 2. Испытание проводится в Российском законодательстве по-русски и в Римском по-латыни. 3. Вопросы могут быть исторические или догматические, или те и другие совокупно, по усмотрению испытующих. 4. Испытуемым предлагается такое число словесных вопросов, какое благоугодно будет испытующим, и, сверх того, предлагается по одному вопросу по жребию, из числа приготовленных заблаговременно двадцати вопросов. На сии письменные вопросы испытуемый в данный срок должен отвечать письменно. 5. По удовлетворительному разрешению испытуемыми сих вопросов, предоставляется им по всем предметам испытания извлечь положения, или тезы, объемлющие весь состав юридических наук... Испытуемый должен защищать их на публичном акте; после чего, если признан будет достойным, получает степень доктора. 6. Наконец, вменяется им в обязанность подготовить впоследствии диссертации и представить их куда следует на рассмотрение». Выписка из высочайше утвержденных правил для испытания на степень доктора прав, обучавшихся в Берлинском университете студентов законоведения ІІ Отделения Собственной канцелярии его величества... ЦГИА. Ф. 418. Оп. 4. Д. 261. Л. 43-44.

2 С 1834 г. Сперанский по поручению императора приступил к преподаванию основ права наследнику престола Александру Николаевичу [Федоров 1997].

3 Выпускники были направлены: в Санкт-Петербургский университет - П.Д. Калмыков, А.И. Кранихфельд, Я.И. Баршев; в Московский - П.Г. Редкий, Н.И. Крылов, С.И. Баршев; в Харьковский - А.А. Федотов-Чеховской, А.В. Куницын, И.В. Платонов; в Киевский - К.А. Неволин, С.Н. Орнатский, С.О. Богородский, В.П. Знаменский - на кафедру законоведения.
} 
юридической политики, повышению уровня правосознания и профессиональной квалификации чиновничества, увеличению их численности с 13 до 41,4\% [Кодан 2005].

\section{Список литературы}

Кодан С.В. 2005. Государственно-правовая подготовка чиновников в России в 1800-1850-е гг. - Чиновникъ. № 1 (35). С. 18-35.

Майков П. 1899а. Сперанский и студенты законоведения. - Русский вестник. № 8 .

Майков П. 1899б. Сперанский и студенты законоведения. - Русский вестник. № 10.

Федоров В.А. 1997. Сперанский и А.А. Аракчеев. М.: Изд-во МГУ. 255 с.

OSIPENKO Svetlana Viktorovna, Cand.Sci. (Hist.), Associate Professor at the Military University of the Ministry of Defense of the Russian Federation (14 Sadovaya St, Moscow, Russia, 123001; sv.osipenko2016@mail.ru)

\section{M. SPERANSKY LAW SCHOOL: FORMATION OF THE NATIONAL MODEL OF SPECIALIZED LEGAL TRAINING}

Abstract. The scientific concept of modern legal policy of the state defines an important task for the scientific community the creation of an effective model of professional education based on historical experience. The article presents the process of formation and development of legal education in Russia in the first half of the $19^{\text {th }}$ century. It also analyzes Speransky's contribution to the formation of the process of specialized training of specialists, the teaching staff of law schools in the context of historical conditions, the influence of the government and society on the process of implementing a progressive legislative plan, an important part of which was the reorganization of the training system.

Keywords: legal education, Russian law, law, law students, law school, justice 